\title{
Bundelkhand Water Woes: Paradigm Shift is Needed in the Strategy
}

\author{
Pratik Ranjan Chaurasia ${ }^{1}$ (D) Subhash Chandra $^{2}$
}

Received: 4 February 2020/Accepted: 25 November 2020/Published online: 2 January 2021

(C) The Institution of Engineers (India) 2021

\begin{abstract}
The Bundelkhand region of Uttar Pradesh, India, is a parched region. Although long-term average annual rainfall of the region is quite sufficient, yet, on a short-term basis, the region is experiencing a sharp negative deviation in rainfall. The region was once a densely forested area and was considered a cloud formation zone. The present analysis shows that the deviation in rainfall correlates with forest cover and calls for a paradigm shift in the region's water resources management strategy to solve the region's water woes in the coming years. The alternative strategy which may change the scenario includes increasing forest cover to mitigate negative deviation in rainfall, implementing group schemes of drip and sprinkler irrigation on a large scale, searching the alternative source of water by developing the integrated facilities to retrieve, treat, store and transport wastewater, enacting comprehensive central water law, improving water efficiency through the Internet of Things, cloud and sensor-based network and large-scale renovation of traditional water bodies as water sanctuaries for groundwater replenishment may change the scenario.
\end{abstract}

Keywords Rainfall · Drought - Irrigation facilities · Water bodies - Forest cover - Wastewater - Water laws . Water efficiency $\cdot$ Base flow $\cdot$ Internet of Things

Pratik Ranjan Chaurasia

pratikcranjan@gmail.com

Subhash Chandra

eemidlko@gmail.com

1 Minor Irrigation Department, Government of Uttar Pradesh, 01/40, Sector- I, Jankipuram, Lucknow 226021, India

2 Department of Minor Irrigation, Government of Uttar Pradesh, 30, Chandralok, Aliganj, Lucknow, India

\section{Introduction}

The Bundelkhand region of Uttar Pradesh, India, is continuously in the news for many years because of water scarcity and persistent drought. The region comprises seven districts of Uttar Pradesh-Banda, Chitrakoot, Hamirpur, Jalaun, Jhansi, Mahoba, and Lalitpur and covers an area of about 29,418 square kilometers. The region's population enumerated at the 2011 population census is about 9.65 million distributed across 4528 villages and 59 towns of varying population size [1]. The region's longterm average annual rainfall has ranged between 800 and $1100 \mathrm{~mm}$, which appears quite promising [2]. The region is, however, still in the news because of water scarcity and frequent drought.

Hard rocks underlay the majority of the region, are devoid of secondary porosity. The heterogeneity in secondary porosity limits hydraulic conductivity reducing the lateral extent of water-bearing formation (aquifer). Even in the limited areas where secondary porosity (joints/fishers) has developed, whatever water column builds up after the monsoon, it gets dissipated rapidly once the groundwater extraction starts in the Rabi season. The yield of dug/bore wells is comparatively higher in the areas where the weathered mantle is relatively thick, but it cannot sustain pumping for prolonged hours. The alluvial areas of the region hold relatively higher promise in terms of groundwater. However, these areas form only a small proportion of the region and have a single aquifer system with a limited alluvium thickness. Being a drought-prone region, the scope of replenishment remains limited [1].

Although the region had sufficient average annual rainfall historically, it has always been a water-scarce area because of its peculiarities. The average annual numbers of rainy days in the region are 46 . Most of the rainfall (85\%) 
occurs in just four months-June, July, August, and September, and the effective number of rainy days during this period, on average, is around 40 . The remaining six rainy days are scattered in the remaining eight months, especially during December and January. During the monsoon, the rainfall intensity is very high-the rainfall may be about $40 \mathrm{~cm}$ in just $20 \mathrm{~h}$. The Vindhyan plateau constitutes the southern part of the region where most impermeable rocks exist at a shallow depth. As one moves north, towards the Yamuna River, the depth of overburden increases, but it remains far less than that in alluvium planes. The region has suffered from over drainage and soil erosion for years because of high slopes, loss of vegetative cover, and less underground space for groundwater storage [3]. Frequent droughts and diminishing rainfall since 200, due to climate change have probably and so obviously aggravated the situation further. In the recent past, all the regional districts have observed a negative deviation in mean annual rainfall. The current strategy of investing in traditional rainwater harvesting structures and recharge measures may not work because of this negative deviation. An alternative approach is needed to address the recently observed negative deviation in the region's average annual rainfall. An essential feature of the region is that the traditional and historical rainwater harvesting and groundwater recharge structures constructed by erstwhile rulers still exist in plenty. Simultaneously, more such structures were constructed/renovated in recent years under many government schemes to boost rainwater harvesting and groundwater recharge. However, because of the diminishing rainfall, sufficient source water is not available to fill these structures. It has been clearly emphasized that in large-scale negative deviations in the average annual rainfall, investment in artificial recharge projects is not recommended [4]. In the above context, this paper attempts to analyze the present scenario in the Bundelkhand region and, based on the analysis, put forward a set of recommendations as to the alternate future strategy.

\section{Diminishing Rainfall in the State and Bundelkhand Region}

The average annual rainfall is continuously diminishing in Uttar Pradesh and the Bundelkhand region of Uttar Pradesh, as seen in Fig. 1. However, the diminishing rate in the average annual rainfall is faster in the Bundelkhand region than in the State as a whole. In Uttar Pradesh, the average annual rainfall during 2001-2010 was $17.77 \%$ less than the long-term average annual rainfall. In the Bundelkhand region, the shortfall was $24.44 \%$, which means that the decline in rainfall in the Bundelkhand region was more pronounced than the State as a whole. This also implies that drought-like conditions prevailed in this region of State during this decade. Several manifestations of drought-like conditions include late arrival of rains, early withdrawal, a long break in between, insufficient water in reservoirs, and drying up of wells leading to crop failures and even un-sowing of the crops, which ultimately hampers livelihood [3].

During the 18th and 19th Centuries, the Bundelkhand region had a draught, on average every 16 years, which increased three times during the period 1968-1992. The most recent and the continued period of insufficient rainfall recorded in the region was during 2004-2010 when below average and erratic rains were recorded in most parts of the region [5]. However, the region received above-normal rainfall in 2011 but, after 2011, the rainfall again turned deficient and erratic. Analysis of rainfall data for the seven districts of the region shows that, in most districts, there was a negative deviation in the rainfall during 2013-2017 (Table 1). It is clear from the table that the year 2013 was a good rainfall year in which all the districts of the region received above-normal rainfall. However, the years 2014 and 2015 were terrible rainfall years in which all the districts of the region received below-average rainfall. The situation was somewhat better in 2016 as three districts received above-average rainfall, but the situation deteriorated again in 2017 as all the districts received belowaverage rainfall. The deficiency in the average annual rainfall was particularly severe in the Mahoba district. During the year 2015, the average annual rainfall deficiency in the district was almost $80 \%$, which had a severe and long-lasting impact on the district's livelihood opportunities. In other districts of the region, the shortfall in the average annual rainfall was quite substantial.

Taking five years average of the actual annual rainfall from Table 1, as we move from the eastern part of the region (district Chitrakoot) and from its western part (district Lalitpur) to its central part (district Mahoba), the deficiency in the average annual rainfall increases. The five-year average deficiency in the average annual rainfall in district Mahoba was more than $40 \%$ compared to only around $10 \%$ in district Chitrakoot, the easternmost district, and around $12 \%$ in district Lalitpur, the westernmost district of the region.

\section{Rainfall During the Monsoon}

Table 2 presents the average rainfall trend during the monsoon months-June, July, August, and September, in the region's districts. The table shows that in Jhansi, Mahoba, Jalaun, and Hamirpur districts, five year average of the rainfall during monsoon months has been below the normal with significant negative deviation in 2014, 2015, 


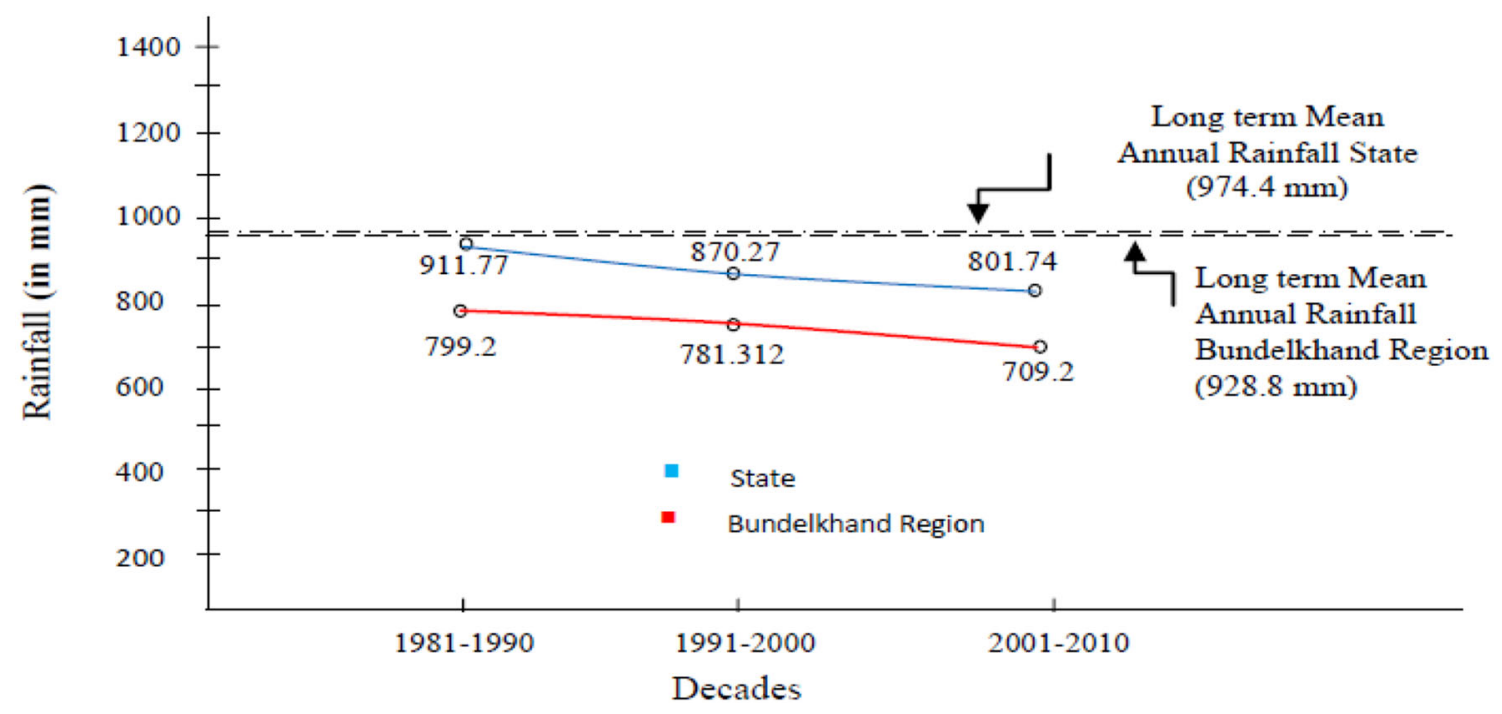

Fig. 1 Decennial mean annual rainfall in Uttar Pradesh, and Bundelkhand region of the state of Uttar Pradesh, India. Data source State Water Resources Agency, Uttar Pradesh, India

Table 1 Shortfall in the average annual rainfall in the districts of Bundelkhand region during 2013-17. Data source Customized Rainfall Information System [2]

\begin{tabular}{|c|c|c|c|c|c|c|c|}
\hline District & & 2013 & 2014 & 2015 & 2016 & 2017 & 5 year average \\
\hline \multirow[t]{3}{*}{ Lalitpur } & Actual & 1684.7 & 810.9 & 449.2 & 919.4 & 674 & 907.64 \\
\hline & Average & 1034.6 & 1034.6 & 1034.6 & 1034.6 & 1034.6 & 1034.6 \\
\hline & Deviation & 62.8 & -21.62 & -56.58 & -11.13 & -34.85 & -12.27 \\
\hline \multirow[t]{3}{*}{ Jhansi } & Actual & 1204.1 & 569 & 533.5 & 640.4 & 468.7 & 683.14 \\
\hline & Average & 931.5 & 931.5 & 931.5 & 931.5 & 931.5 & 931.5 \\
\hline & Deviation & 29.26 & -38.9 & -42.72 & -31.25 & -49.68 & -26.66 \\
\hline \multirow[t]{3}{*}{ Jalaun } & Actual & 894.8 & 502.7 & 450.1 & 700.14 & 361.8 & 581.96 \\
\hline & Average & 871.5 & 871.5 & 871.5 & 871.5 & 871.5 & 871.5 \\
\hline & Deviation & 2.67 & -42.31 & -48.35 & -19.63 & -58.48 & -33.22 \\
\hline \multirow[t]{3}{*}{ Mahoba } & Actual & 868.8 & 379.8 & 181.2 & 843.3 & 274.3 & 509.48 \\
\hline & Average & 853.1 & 853.1 & 853.1 & 853.1 & 853.1 & 853.1 \\
\hline & Deviation & 1.84 & -59.48 & -78.75 & -1.1 & -67.8 & -40.27 \\
\hline \multirow[t]{3}{*}{ Hamirpur } & Actual & 1136.5 & 485.1 & 470.4 & 960.6 & 380 & 686.52 \\
\hline & Average & 881.8 & 881.8 & 881.8 & 881.8 & 881.8 & 881.8 \\
\hline & Deviation & 28.88 & -44.98 & -46.69 & +8.9 & -56.9 & -22.14 \\
\hline \multirow[t]{3}{*}{ Banda } & Actual & 984.6 & 639.2 & 676.9 & 1230.5 & 508.3 & 867.9 \\
\hline & Average & 943.2 & 943.2 & 943.2 & 943.2 & 943.2 & 943.2 \\
\hline & Deviation & 4.389 & -32.33 & -28.23 & +30.4 & -46.10 & -14.34 \\
\hline \multirow[t]{3}{*}{ Chitrakoot } & Actual & 1318.3 & 665.9 & 531.1 & 1073 & 834.5 & 884.56 \\
\hline & Average & 986.3 & 986.3 & 986.3 & 986.3 & 986.3 & 986.3 \\
\hline & Deviation & 33.66 & -32.48 & -46.15 & +8.79 & -15.39 & -10.3 \\
\hline
\end{tabular}

and 2017 resulting in a drought-like situation. Lalitpur, Banda, and Chitrakoot districts also have a negative deviation, but the rainfall deficiency in these districts was less than $20 \%$ of the average rainfall.

A comparison of Table 1 and Table 2 suggests that districts' deficiency in districts' monsoonal rainfall follows a similar pattern as of annual rainfall. It further suggests that deficiency in rainfall in Lalitpur, Jhansi, Jalaun, Banda, Hamirpur, and Chitrakoot districts has been more in the monsoon months to the total rainfall during the year on average. However, in Mahoba district, the deficiency in the rainfall has been more in the non-monsoon months. 
Table 2 Rainfall during the monsoon months in districts of Bundelkhand

\begin{tabular}{|c|c|c|c|c|c|c|c|}
\hline District & & 2013 & 2014 & 2015 & 2016 & 2017 & Five years average \\
\hline \multirow[t]{3}{*}{ Lalitpur } & Actual & 1486.9 & 633.8 & 321.3 & 920.2 & 658 & 804 \\
\hline & Average & 939.3 & 939.3 & 939.3 & 939.3 & 939.3 & 939.3 \\
\hline & Deviation & 58.2 & -32.5 & -65.79 & -2.0 & -29.14 & -14.4 \\
\hline \multirow[t]{3}{*}{ Jhansi } & Actual & 929.8 & 399.1 & 389.8 & 589.5 & 453 & 552.24 \\
\hline & Average & 837.9 & 837.9 & 837.9 & 837.9 & 837.9 & 837.9 \\
\hline & Deviation & 10.9 & -52.36 & -53.67 & -29.6 & -45.9 & -34.09 \\
\hline \multirow[t]{3}{*}{ Jalaun } & Actual & 756.7 & 353 & 316.6 & 638.5 & 319.4 & 476.84 \\
\hline & Average & 774.9 & 774.9 & 774.9 & 774.9 & 774.9 & 774.9 \\
\hline & Deviation & -2.3 & -54.44 & -59.14 & -17.6 & -58.78 & -38.46 \\
\hline \multirow[t]{3}{*}{ Mahoba } & Actual & 739.8 & 258.8 & 251.8 & 823.1 & 480.1 & 510.72 \\
\hline & Average & 776.4 & 776.4 & 776.4 & 776.4 & 776.4 & 776.4 \\
\hline & Deviation & -4.7 & -66.6 & -67.56 & +6.0 & -38.16 & -34.2 \\
\hline \multirow[t]{3}{*}{ Banda } & Actual & 1083.6 & 339.2 & 476.9 & 1164 & 492.9 & 711.32 \\
\hline & Average & 840.4 & 840.4 & 840.4 & 840.4 & 840.4 & 840.4 \\
\hline & Deviation & 28.9 & -59.6 & -43.25 & +38.5 & -41.34 & -15.35 \\
\hline \multirow[t]{3}{*}{ Hamirpur } & Actual & 919.5 & 342.4 & 342.2 & 878.2 & 340.4 & 564.54 \\
\hline & Average & 796.9 & 796.9 & 796.9 & 796.9 & 796.9 & 796.9 \\
\hline & Deviation & 15.38 & -57.0 & -57.0 & +10.2 & -57.2 & -29.15 \\
\hline \multirow[t]{3}{*}{ Chitrakoot } & Actual & 1134.2 & 433.8 & 340.4 & 1044.5 & 833 & 757.18 \\
\hline & Average & 885.9 & 885.9 & 885.9 & 885.9 & 885.9 & 885.9 \\
\hline & Deviation & 28 & -51.0 & -61.57 & +17.9 & -5.9 & -14.5 \\
\hline
\end{tabular}

\section{Aquifer System and Groundwater Resource of the Bundelkhand Region}

Bundelkhand region has diverse hydrological conditions. Based on the nature and extent of their hydrological properties concerning groundwater flow characteristics, the formations are broadly categorized as Consolidated (Crystalline and Vindhyan) or Unconsolidated.

The crystalline formations, composed of old metamorphic, are granite, gneisses, and quartz reefs. These are hard and compact with limited primary porosity resulting in poor aquifers. The porosity of hard crystalline rocks varies from 0 to $0.03 \%$ and, therefore, is incapable of holding or transmitting substantial water. However, along the plane of weakness, like, joints, fractures, and shear planes, the weathering and decomposition impart appreciable porosity and permeability. The porosity of the weathered zone varies from 30 to 50\%. The wells placed in such a zone sometimes yield copious water. Generally, dug wells in these formations have a depth range of $5-30 \mathrm{~m}$. The Vindhyan formations are composed of sandstone, shale, and limestone. The sandstones and shales are hard and compact and hence, form a poor aquifer.

The unconsolidated formations occurring south of river Yamuna in Jalaun, Hamirpur, and Banda districts, form the hydrological unit known as "Marginal Alluvial Plain." The sediments mainly comprise clay-pebble-silt with intercalation of sand and gravel lenses of varying thickness with primary inter-granular porosity. The thickness of these sediments varies from 50 to $150 \mathrm{~m}$. Groundwater occurs in this unit under water table conditions in the upper zone (i.e., within $40 \mathrm{~m}$ depth) and under semi-confined conditions at a deeper level (i.e., below $40 \mathrm{~m}$ depth) [1].

Dynamic groundwater resource is assessed periodically in the State, and the last assessment was made in the year 2017. Table 3 shows district wise dynamic groundwater resource in the Bundelkhand region.

Table 3 shows that groundwater extraction is highest in district Mahoba, followed by district Chitrakoot, Lalitpur, and Hamirpur, where it is more than $70 \%$. In other districts, the percentage of groundwater extraction is less than $70 \%$.

Between the years 2006 and 2016, 60\% of the region's wells show falling of groundwater levels up to $4 \mathrm{~m} \mathrm{[7].} \mathrm{So}$ it can be said that there is a widespread fall of groundwater levels in the region.

\section{Irrigation Facilities in the Bundelkhand Region}

Source wise irrigated area in the Bundelkhand region is presented in Table 4.

Table 4 suggests that the area irrigated by private tube wells and other sources is $63.85 \%$. Under others, dug wells are the major source owned by individuals. So, private 
Table 3 Dynamic groundwater resource in the Bundelkhand region as on 31.03.2017 In million cubic meters. Data source Statistical diary of Uttar Pradesh, 2019 [6]

\begin{tabular}{lllll}
\hline $\begin{array}{l}\text { S. } \\
\text { No }\end{array}$ & District & $\begin{array}{l}\text { Annual } \\
\text { dynamic } \\
\text { recharge }\end{array}$ & $\begin{array}{l}\text { Annual } \\
\text { net } \\
\text { extraction }\end{array}$ & $\begin{array}{l}\text { \% of annual extraction to } \\
\text { annual dynamic recharge }\end{array}$ \\
\hline 1 & Lalitpur & 400 & 313 & 78.33 \\
2 & Jhansi & 849 & 422 & 49.65 \\
3 & Jalaun & 1061 & 523 & 49.32 \\
4 & Mahoba & 217 & 191 & 87.77 \\
5 & Hamirpur & 429 & 309 & 72.05 \\
6 & Banda & 596 & 402 & 67.36 \\
7 & Chitrakoot & 367 & 300 & 81.79 \\
\hline
\end{tabular}

Table 4 Source wise irrigated area (2015-16). Data source Statistical diary of Uttar Pradesh, 2019 [6]

\begin{tabular}{llll}
\hline S. No & Source & $\begin{array}{l}\text { Irrigated area } \\
\text { (Hectare) }\end{array}$ & Percentage \\
\hline 1 & Canals & 361,327 & 30.98 \\
2 & Government tube well & 61,185 & 5.246 \\
3 & Private tube wells & 471,156 & 40.403 \\
4 & Others & 273,465 & 23.45 \\
& (Dug wells, ponds, etc.) & & \\
& Total & $1,166,138$ & 100 \\
\hline
\end{tabular}

minor irrigation structures are the main source of irrigation, followed by canals.

The region has various minor irrigation structures such as dug wells, tube wells, surface flow, and surface lift schemes. Minor irrigation structures used for irrigation are presented in Table 5 [8].

Table 5 shows that dug wells and shallow tube wells are the main minor irrigation structures in the region. It also suggests that the majority of minor irrigation structures are groundwater based.

Sown area and irrigated area vary year to year depending upon weather conditions. In 2015-16, the region's net sown area was 1.952 million hectares, of which the net irrigated area was 1.166 million hectares or $57.17 \%$ of the net sown area, while the percentage of the net irrigated area to the net sown area of the State is about $87 \%$. Mahoba is the least irrigated district, having just $25 \%$ irrigated area. District Jalaun is the most irrigated, having $76 \%$ irrigated area followed by Jhansi, $72 \%$, Lalitpur, $72 \%$, Hamirpur, 61\%, Banda, 57\%, and Chitrakoot, 53\% [6].

Surface pipes and open channels are widely used with minor irrigation structures for the distribution of irrigation water. Share of water-efficient irrigation systems like sprinkler and drip is meager, as is clear from Table 6 [8].

\section{Water Bodies in the Bundelkhand Region}

There are plenty of water bodies in the region. Erstwhile rulers of the region traditionally built the majority of them. Though water bodies of the region are not properly mapped, according to available information, district wise numbers of ponds are presented in Table 7.

Apart from this, there are 59 large dams and tanks with approximate reservoir areas of about 70,000 hectares [9] and numerous small water bodies such as check dams, farm tanks, earthen bundhs, etc. in the region.

\section{Soil and Crops}

Mixed red and black soil having low moisture-holding capacity and fertility is found in the region. Black soil is sticky and calcareous. It expands as it soaks moisture and contracts on drying up. In the upper plateau of the region's seven districts, the soil is red and is of two kinds"Prawa" and "Rakar." Parwa is light sandy or sandy loam, while Rakar is alkaline. Soils of the region have low to very low nitrogen availability, very deficient phosphorus availability, and medium to high potash availability. Sulfur availability is marginal to deficient. Among micronutrients, only zinc is marginally available; the rest are sufficient [1] and [7].

The maximum area is covered under wheat followed by pulses, gram, sesame, rice, pigeon pea, rapeseed, mustard, and barley. The area under fruit and plantation and drug crops is only $0.011 \%$ and $0.19 \%$, respectively. Among major crops, the area under wheat crop is highest, whose water requirement is comparatively very high compared to other significant crops [7]. Due to fewer irrigation facilities, the maximum area is sown in Kharif (monsoon) season. The sown area in the Rabi season is about half of the area sown in the Kharif season, and the sown area in Zaid season is about $1 \%$ of the area sown in the Kharif (monsoon) season [1].

Cropping intensity of the region is about $140 \%$, district Lalitpur having the highest (180\%) followed by Jhansi (165\%), Mahoba (143\%), Banda (130\%), Hamirpur (128\%), and Chitrakoot (113\%). Cropping intensity of the State is $158 \%$ [7].

\section{Forest Cover and Deviation in Rainfall}

The Nation's forest policy declared after independence envisaged to develop forests in one-third of the land area. However, in the State of Uttar Pradesh, India, and its Bundelkhand region, forest cover remained far below this 
Table 5 Minor irrigation Structures in the Bundelkhand region (2013-14)

\begin{tabular}{llll}
\hline S. No & Type of structure & Numbers & Percentage \\
\hline 1 & Dug wells & 84,609 & 53.11 \\
2 & Shallow tube wells & 43,113 & 27.06 \\
3 & Medium deep tube wells & 14,331 & 8.99 \\
4 & Deep tube wells & 5141 & 3.22 \\
5 & Surface flow schemes & 4595 & 2.88 \\
6 & Surface lift schemes & 7503 & 4.71 \\
& Total & 159,292 & 100 \\
\hline
\end{tabular}

Table 6 Water distribution methods used by minor irrigation structures. Data source As per 5th Census of Minor Irrigation Schemes, the reference year 2013-14

\begin{tabular}{ll}
\hline $\begin{array}{l}\text { Water distribution } \\
\text { method }\end{array}$ & $\begin{array}{l}\text { \% of minor irrigation structures using water } \\
\text { distribution method }\end{array}$ \\
\hline $\begin{array}{l}\text { Open channel (lined } \\
\text { and unlined) }\end{array}$ & 47.08 \\
Surface pipe & 48.58 \\
Underground pipe & 1.44 \\
Drip & 0.58 \\
Sprinkler & 1.75 \\
Others & 0.66 \\
\hline
\end{tabular}

target. After the formation of the new State of Uttarakhand, separating the hilly region of Uttar Pradesh in the year 2000 , forest cover came down drastically and remains stagnant at around $6 \%$ in the State and around $6.5 \%$ in the Bundelkhand region, far below the targeted one-third area.

Forest cover in the State of Uttar Pradesh, India, and in the Bundelkhand region of Uttar Pradesh since 2001 is shown in Table 8.

Forest statistics of the seven districts of the Bundelkhand region of Uttar Pradesh is shown in Table 9 [10].

Table 9 shows that in the 2017 assessment, forest cover increased marginally in all the districts, however still far below one-third of the area. Further, barring Lalitpur and Chitrakoot districts, forest cover remained below $10 \%$.
Chitrakoot is the most forested district in the region, with an $18.22 \%$ forest area, followed by Lalitpur, with $11.65 \%$ forest area. District Banda is the least forested, having only a $2.31 \%$ forest area.

A comparison of five years' average deviation in rainfall during 2013-2017 and forest cover (2017assessment) in the seven districts of the Bundelkhand region is shown in Fig. 2.

Figure 2 suggests that the districts with less forest cover have a high deviation in rainfall and vice-versa. In those districts where forest cover is around 6\%, rainfall deficiency is around $30 \%$, while in those districts where forest cover is more than $10 \%$, rainfall deficiency is around $10 \%$ only. However, in Mahoba and Banda districts, the situation is somewhat different. Despite $2.31 \%$ of forest cover in the Banda district, rainfall deficiency is only- $14.54 \%$, far less than other districts. It may be because the district Chitrakoot before its formation was part of the district Banda. If these two districts' figures are combined, forest cover comes out to be $9.01 \%$, and the deviation in rainfall as-9.175\%, which is similar to other districts' trend. Similarly, the district Mahoba, before its formation, was part of the district Hamirpur. If the figures of these two districts are combined, forest cover comes out to be 5.54\% and deviation in rainfall as- $31 \%$, which is similar to other districts' trend. With these modifications, a comparison of five years' average annual deviation in rainfall and forest cover is shown in Fig. 3.

Table 7 District wise numbers of ponds. Data source Circle office, Minor Irrigation Department, Uttar Pradesh

\begin{tabular}{llll}
\hline District & Less than one hectare & More than one hectare & Total \\
\hline Lalitpur & 127 & 108 & 235 \\
Jhansi & 478 & 188 & 666 \\
Jalaun & 1447 & 167 & 1614 \\
Mahoba & 755 & 317 & 1072 \\
Hamirpur & 1283 & 284 & 1567 \\
Banda & 2695 & 600 & 3295 \\
Chitrakoot & 1258 & 314 & 1572 \\
Total & 8043 & 1978 & 10,021 \\
\hline
\end{tabular}


Table 8 Forest cover in the state of Uttar Pradesh, India. Data source State of the Forest Report [10]

\begin{tabular}{llll}
\hline \multirow{2}{*}{ S. No } & Assessment year & \multicolumn{2}{l}{ Forest cover in \% of geographical area } \\
\cline { 3 - 4 } & & State & Bundelkhand region \\
\hline 1 & 2001 & 5.71 & 6.27 \\
2 & 2003 & 5.86 & 6.62 \\
3 & 2005 & 5.86 & 6.62 \\
4 & 2009 & 5.95 & 6.66 \\
5 & 2011 & 5.95 & 6.66 \\
6 & 2013 & 5.96 & 6.77 \\
7 & 2015 & 6.00 & 6.72 \\
8 & 2017 & 6.09 & 6.55 \\
\hline
\end{tabular}

Figure 3 indicates the relationship between forest cover and deviation in rainfall as the percentage of negative rainfall deviation reduces with the increase in forest cover percentage. However, the proportion varies among the districts. Data set related to Fig. 3 is presented in Table 10.

The correlation coefficient calculated by the Pearson correlation formula between the variables presented in Table 10 comes out to be 0.90 , which is a very strong corelation and indicates that negative deviation in rainfall decreases with an increase in forest cover. Thus, it can be concluded that in these districts, had the forest cover been one-third of the geographical area, the adverse impact of climate change on rainfall deviations would have minimized. In other words, it can be said that increasing the forest cover may be an effective intervention to mitigate the adverse impact of climate change on rainfall deviations.

The relation between vegetation and precipitations (rainfall/snowfall) had been a debatable issue. However, in the recent past, a consensus is again developing that there is a relation between precipitation and vegetation. The "Global Landscapes Forum" conducted a session on "Precipitation and its Relation to Vegetation" to show the role of forest and trees in the water cycle and how to influence the climate through atmospheric water cycle controls [11]. A new hypothesis suggests that forest cover plays a much more significant role in determining rainfall than previously recognized. It explains how forested regions generate large-scale flows in atmospheric water vapors. Under this hypothesis, high rainfall occurs in continental interiors such as Amazon and Congo river basins only because of near-continuous forest cover from the interior coast. The underlying mechanism emphasizes the role of evaporation and condensation in generating atmospheric pressure differences and accounts for several phenomena neglected by existing models. It suggests that even localized forest loss can sometimes flip a wet continent to arid conditions. If it survives scrutiny, this hypothesis will transform how we view forest loss, climate change, hydrology, and environmental services [12].

Narrated analysis of the Bundelkhand region very clearly supports the above hypothesis.

\section{Future Strategies}

To address the Bundelkhand region's water woes, the state government adopted the strategy of constructing a large number of rainwater harvesting structures under different government schemes so that more and more rainwater could be harvested and groundwater could be replenished. However, this strategy did not succeed as the region's unexpected climate change effects were more severe and sharp. This strategy was primarily based on the long-term average annual rainfall, which did not consider the substantial negative deviation based on the short-term average annual rainfall. The strategy was also implemented homogeneously in all the districts with little consideration to inter-district variation in the rainfall across the region's districts. A more appropriate approach would have been to adopt a district-specific strategy to consider the prevailing district-specific hydrological conditions.

A state government effort to address water scarcity in the region was followed by the "Bundelkhand Package" by the Government of India, which covered the Bundelkhand region of Uttar Pradesh and Madhya Pradesh. Although the package's aim was drought-proofing of the region, it was ill-designed and did not consider the ground realities seriously. For example, the package aimed at digging 20 thousand dug wells in the Uttar Pradesh part of the region at a unit cost of INR 0.1 million. There was little consideration to analyze the operational feasibility of the set targets under the package-whether such a large number of dug wells could be constructed with the present infrastructure within the given time frame. The early experience suggested that the cost per dug well was too low to construct a well properly. Subsequently, the cost per dug well was revised to INR 0.283 million per dug well and then to INR 0.315 million, but the dug wells' target was reduced substantially. Similarly, many emphases were given to the marketing infrastructure without considering water availability to ensure extra production. The diminishing rainfall in the region since 2001 clearly showed that the rainfall is no more a reliable source of water supply now. On the other hand, the strategy ignored, totally, renovation of traditional water bodies. There are large numbers of traditional water bodies in dilapidated conditions at present as their storage and recharge capacity is reduced considerably over time due to many well-known factors. Renovation of these structures has the potential to change the present scenario. 
Table 9 Forest cover in the seven districts of the Bundelkhand region of Uttar Pradesh, India

\begin{tabular}{llccc}
\hline S. No & Name of the district & $\begin{array}{l}2013 \text { assessment } \\
\% \text { of geographical Area }\end{array}$ & $\begin{array}{l}2015 \text { assessment } \\
\% \text { of geographical area }\end{array}$ & $\begin{array}{l}2017 \text { assessment } \\
\% \text { of geographical area }\end{array}$ \\
\hline 1 & Lalitpur & 11.35 & 11.35 & 11.65 \\
2 & Jhansi & 4.26 & 4.26 & 6.03 \\
3 & Jalaun & 5.37 & 5.37 & 5.45 \\
4 & Mahoba & 3.29 & 3.29 & 5.41 \\
5 & Hamirpur & 4.06 & 4.06 & 5.65 \\
6 & Banda & 2.27 & 2.27 & 2.31 \\
7 & Chitrakoot & 18.21 & 18.56 & 18.22 \\
\hline
\end{tabular}

Fig. 2 Forest cover and deviation in rainfall

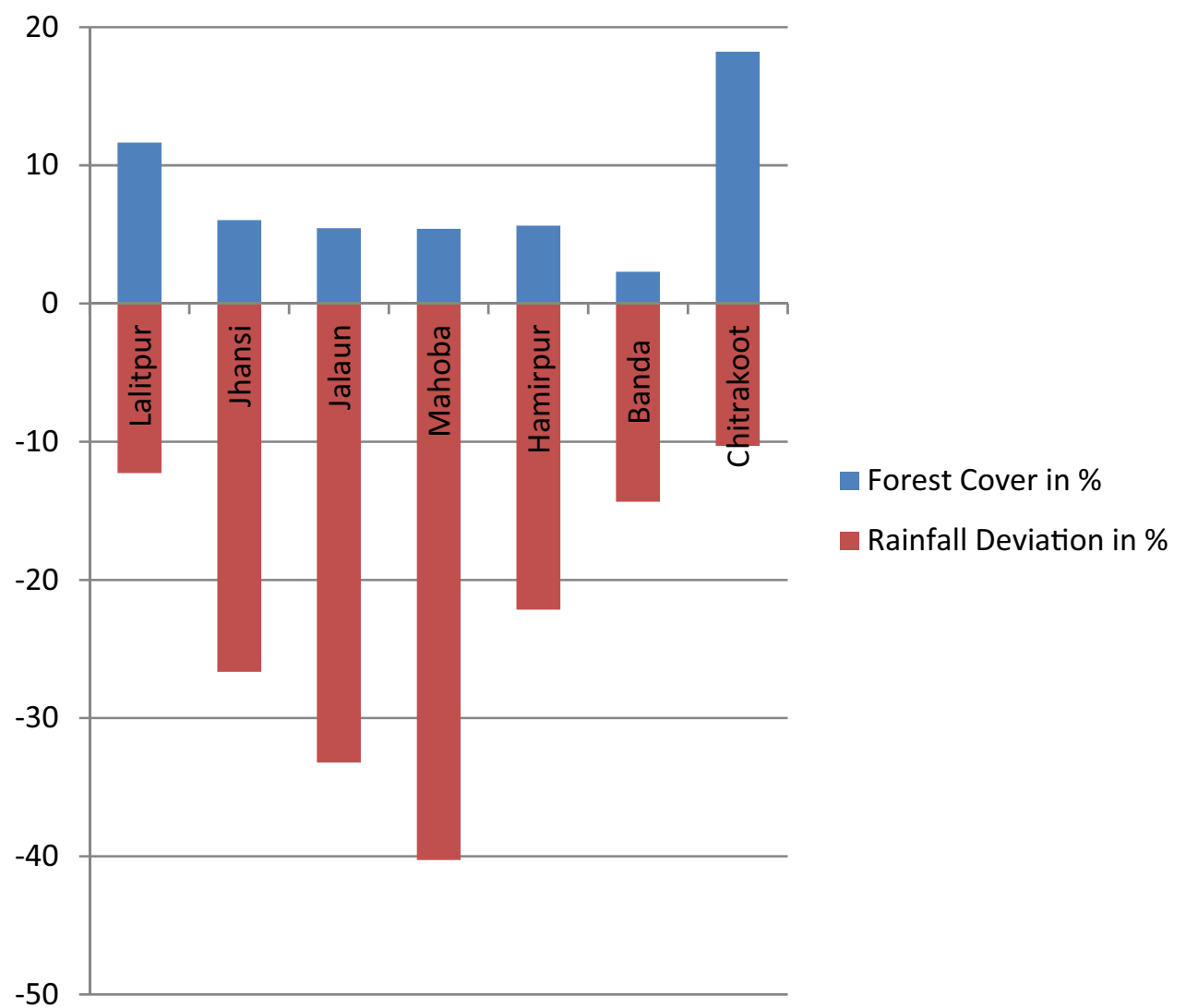

A paradigm shift in the current strategy is needed to counter the effects of a fast-changing climate in the region, including negative rainfall deviation. In this context, the following issues need serious consideration:

1. The first issue is how to increase the forest cover? Presently forest cover in the Bundelkhand region is $6.55 \%$, and Chitrakoot is the only district having a dense forest in the region [6]. In every village, the forest area of about 100 hectares should be developed depending on the availability of land. This approach will add up to about $15 \%$ forest cover, which will help achieve the target of $30 \%$ forest cover and mitigate the impact of negative deviation in rainfall on account of climate change. Moreover, this approach will lead to even distribution of the forest cover across the region. Special laws can be promulgated for this, and if the land is not available, it may be acquired. If the land for highways, airports, and industrial zones can be acquired, the same can be done in forestation and linked to our future survival.

The latest technologies to develop forest rapidly as adopted by Japan in small patches may be innovative. To implement this approach creation of an independent authority or special purpose vehicle is suggested.

2. The second issue is how to improve the per unit productivity of water. The water use efficiency can be improved by promoting the use of sprinkler/drip 
Fig. 3 Forest cover and deviation in rainfall

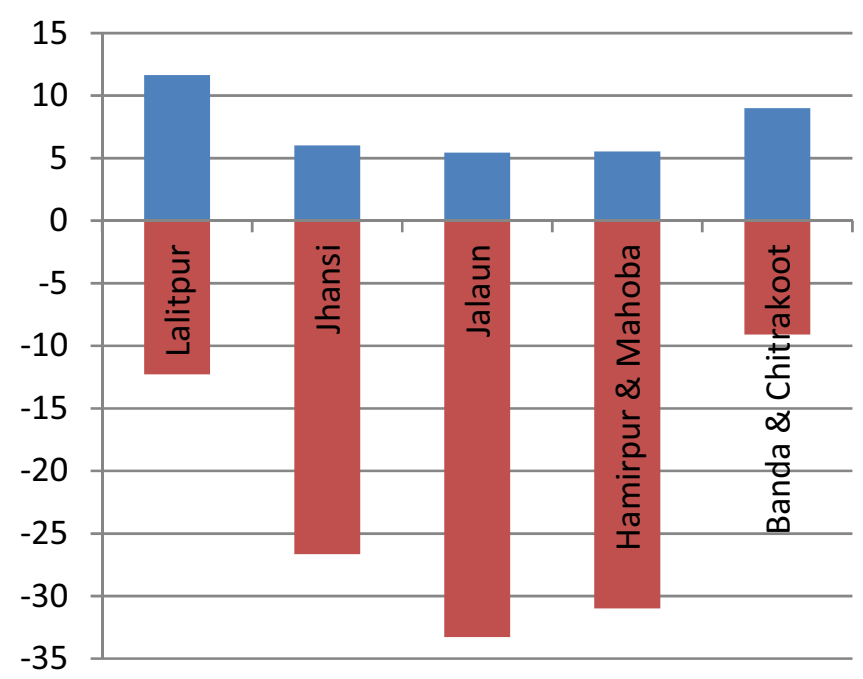

Forest Cover in \%

Rainfall Deviation in \%
Table 10 Data set related to Fig. 3

\begin{tabular}{llll}
\hline $\begin{array}{l}\text { S. } \\
\text { No }\end{array}$ & Name of the district & $\begin{array}{l}\text { Forest cover } \\
(\%) \\
(\mathrm{X})\end{array}$ & $\begin{array}{l}\text { Rainfall deviation } \\
(\%) \\
(\mathrm{Y})\end{array}$ \\
\hline 1 & 2 & 3 & 4 \\
1 & Lalitpur & 11.35 & -12.27 \\
2 & Jhansi & 6.03 & -26.66 \\
3 & Jalaun & 5.45 & -33.22 \\
4 & Mahoba and & 5.54 & -31.00 \\
5 & Hamirpur & 9.01 & -9.17 \\
& Banda and Chitrkoot & & \\
\hline
\end{tabular}

irrigation in place of flood irrigation, which is the norm in the region. Farmers at large still irrigate their fields by flood irrigation, having the lowest water use efficiency. Fifth Minor Irrigation Census data show that only $0.25 \%$ of minor irrigation schemes in Uttar Pradesh, India, use a sprinkler irrigation/drip irrigation system. Though there is a $100 \%$ increase as compared to the fourth minor irrigation census, it is negligible. In the Bundelkhand region, this figure is $2.33 \%$ in the Fifth Minor Irrigation Census, about 168\% higher than the Fourth Minor Irrigation Census figure of 0.87\% [8] and [13]. To promote sprinkler/drip irrigation, there is a need to change the present crop rotation and agriculture practices, which can be done by choosing a crop rotation in line with water availability at the block/district level. It can be achieved by reducing the area under water-intensive wheat crop and increasing area under fruit plantation crops like citrus, guava, amla (Phyllanthus Emblica) should be the critical intervention. Further, despite $90 \%$ subsidy, coverage under drip and sprinkler is insignificant, indicating that these schemes have not shown the desired results.
Thus, the complete overhaul of the present Micro Irrigation Program concerning individual subsidybased drip and sprinkler irrigation schemes is urgently needed. One reason may be land holdings' size because the percentage of landholding size below one hectare is very high $(79.5 \%)$ in the State. So, instead of individual subsidy-based schemes, group schemes may be more effective. For example, a group scheme to develop horticulture complexes with a centralized drip irrigation system may be more useful to increase coverage under drip than the individual subsidy-based schemes. This will also enhance the green canopy in the region and Zaid cultivation. Similarly, the sprinkler irrigation system may be promoted through well-designed group schemes under which water can be lifted from reservoirs/canals and applied through a permanent sprinkler irrigation system.

3. The third is how to develop new and alternative sources of water? By 2030, India's water demand will be twice of water supplies [14]. With reducing rainfall and growing demand search for reliable alternative sources of water becomes imperative. Wastewater may be one of such reliable and potential water sources as it is available round the year in the same quantity. Over several decades, Israel already did it by building national wastewater infrastructure to make use of wastewater, especially, for irrigation and presently reuses $85 \%$ of its wastewater. It has developed an integrated wastewater facility through which wastewater is collected, treated, stored, and transported through a network of pipelines to arid areas for irrigation [15].

Accurate and consolidated information regarding generated wastewater is not available for the State of Uttar Pradesh. However, it is also true that it is a large State, 
has 45 million urban populations approximately and generates large quantities of wastewater daily. Sixtythree cities/towns in the State have a population of 0.1 million or more. Out of these, seven cities have a population of one million or more. Allahabad and Kanpur are two such cities, having a population of 1.168 million and 2.76 million, respectively, near to the Bundelkhand region. Lucknow, having a population of 2.8 million, is also nearby. The Bundelkhand region has four cities with a population of 0.1 million or more, with a combined population of 1.034 million. The other four nearby towns of over 0.1 million population have a combined population of 0.7 million. The combined population of all these becomes about 8.462 million, approximately equal to Israel's population [6] and [15]. The average consumption of freshwater is 135-150 L per capita per day (lpcd). If we take daily per capita freshwater consumption as $135 \mathrm{~L}$, per capita wastewater generated is $90 \%$ or about 121 lpcd. However, it is the most conservative estimate; in actual practice, it will be much more. For a population of 8.462 million, the amount of generated wastewater comes to be 373.7 million cubic meters (MCM) per year. It does not include wastewater generated from industries, generally 50-60\% of domestic wastewater [16] and [17]. Total wastewater generated will be around 579 MCM, which is about $15 \%$ of the region's total annual recharge. It is a huge quantity, most reliable, available round the year in the same amount. It will increase with an increasing population, which can be used to supplement the irrigation water demand of the parched Bundelkhand region. Instead of limiting the strategy to rainwater harvesting, it is now the right time to develop the integrated facilities to retrieve, treat, store and transport the wastewater so that in case of emergencies, it can be used to supplement the demand of the parched region.

4. There is also a need to review water's constitutional and legal status and enact a central law to control the Nation's water effectively. There are contradictions in the provisions of different legislations and create more confusion. The Constitution says that water is a state subject, but the National Water Policy says it is a national resource. The Environment Protection Act 1986, which is a central act, also covers water. Easement Act 1886 says that the owner of the land is the owner of water beneath it. There are other laws also which deals with water tax, pollution of water, and others. India's national government has circulated a model bill on groundwater for the last 30 years, but it is still in limbo. Some states have also passed acts on groundwater, but their implementation is inferior and ineffective [18].

5. Information technology may also contribute to addressing the situation. Unfortunately, the penetration of information technology in the irrigation and water sector is negligible. Farmers of the region traditionally irrigate crops. They have little information/knowledge about changing climate and rainfall patterns and what and how to do in the changing situation. Information Technology can promote automation in irrigation, thereby reducing the wastage of water and improving water efficiency. As the world is trending to modern technologies, it is necessary to trend up the irrigation/ agriculture sector. In combination with wireless sensor networks, the Internet of Things and cloud can lead to agriculture modernization and automatize irrigation. Wireless sensor network monitors parameters like temperature, humidity, rainfall, soil moisture, and analyses threshold values to start or stop irrigation or need of fumigation. These modern technologies have great potential to improve efficiency and must be tried at the earliest to prove their efficacy in actual field conditions for their large-scale adoption. Apart from this, using weather and climate data specific to the district, suitable models can be developed to forecast future action in advance and communicated to the farmers through a mobile application. In today's rapid technological advancements, no state can afford to be technologically backward.

6. Finally, there is a need to improve water supply through traditional water bodies/ponds, most of which are currently in very dilapidated conditions. Traditionally, every village had more than one pond, and they are still plenty in the Bundelkhand region. However, after independence, due to preoccupation to develop water to fulfill the growing demand for irrigation and other sectors, these water bodies/ponds were overlooked, and no attention was paid to their maintenance and upkeep. Traditionally, these were also the community's religious-cultural centers, and the community use to preserve these as water sanctuaries. The neglect of these ponds ultimately resulted in reducing their capacity to harvest and store rainwater substantially due to heavy siltation over time. Many of these were encroached upon due to urbanization and agricultural activities expansion and existed only on paper. The major thrust for their renovation and de-siltation came when rainwater harvesting works were given priority in centrally sponsored Mahatma Gandhi Rural Employment Guarantee Scheme, launched by the Government of India the year 2006. Large numbers of small size ponds were de-silted under this scheme in the State. However, being an employment guarantee 
scheme, the use of machinery is forbidden. Large-sized ponds ( $>1$ hectare) requiring heavy earth movement could not be de-silted under it.

Thus, there is a need to formulate a separate scheme for redevelopment and renovation of all the large ponds ( $>1$ hectare) and other large water bodies like dams/tanks in a time-bound manner to restore their water storage and recharge capacity. All such water bodies should be mapped, renovated, protected, and preserved as water sanctuaries, thus improving water supply, checking falling groundwater levels, and improving base flow into the rivers. Revitalization of the traditional water bodies in the region should also be accompanied by promoting water as the common property resource for the people, needs to be protected and enhanced by the community for the community's benefit. Community-level water conservation is the key to improving water supply at the local level, and concepts like "Pani Panchayat" may be introduced for it.

\section{Conclusion}

The present paper argues that to solve water woes of the parched Bundelkhand region of the State of Uttar Pradesh, India, a paradigm shift in the current strategy is urgently needed. Out of box solutions like increasing forest cover up to $30 \%$ by developing 100 hectares of dense forest in each village to mitigate extreme negative rainfall deviations on account of climate change, designing and promoting largescale sprinkler/drip irrigation community schemes instead of individual schemes, creating the integrated facilities to retrieve, treat, store and transport wastewater to the parched region as an alternative source of water, enacting comprehensive central water law, improving the water efficiency of the system through information technology and enhancing water supplies through redevelopment and renovation of sizeable traditional water bodies and developing them as water sanctuaries for groundwater replenishment may contribute significantly towards the effective solution of the water woes of the region.

\section{References}

1. Khan Seraj, Hydrogeology of Uttar Pradesh (Central Ground Water Board, Northern Region Lucknow, Ministry of Water Resources, River Development and Ganga Rejuvenation, Government of India, 2017) pp.xvi,4,12, 43, 44
2. Customized Rainfall Information System (Hydro met Division, India Metrological Departments, Ministry of Earth Sciences, New Delhi, India) Online. http://hydro.imd.gov.in/hyrometweb/ District rainfall. Accessed in Apr 2018

3. Prakash, Bhartendu, Ghosh, Shailendra M., Satya, Santosh \& Chaurasiya, L.P., Problems and Potential of Bundelkhand with special reference to Water Resource Base (Center for Rural Development and Technology, India, Indian Indian Institute of Technology, Delhi and Vigyan Siksha Kendra, Attara (Banda), 1998) U.P., pp 2-8

4. Manual of Artificial Recharge of Ground Water (Central Ground Water Board Faridabad, Ministry of Water Resources, Government of India, 1984) pp 15-16

5. Gupta, A.K., Nayar, Sreeja S., Ghosh, Oishance, Singh, Anjali, Dev, Sunand, Bundelkhand Draught - A Perspective Analysis and Way Ahead, (National Institute of Disaster Management, New Delhi 2014), pp. 2-8

6. Statistical Diary, Uttar Pradesh, 2019 (Economics and Statistics Division, State Planning Institute, Uttar Pradesh. 2020) pp 60, 62, 63,152-188

7. Options and Strategies for Farmers' Income Enhancement in the Bundelkhand region of Central India (Central Agroforestry Research Institute, Jhansi, 2018) Online. http://cafri.in/ technicalbulletin/

8. Fifth Census of Minor Irrigation works (Ministry of Water Resources, River Development and Ganga Rejuvenation, Government of India, the Reference year 2013-14) Online. www.mowr.gov.in

9. World Bank Schemes/National Hydrology Project (Irrigation and Water Resource Department UP) Online. http://idup.gov.in/ pages/en/topmenu/w.b.-aided-projects/en-national-hydrologyproject-nhp. Accessed in Mar 2020

10. State of the Forest Report, Uttar Pradesh, 2001-2017 (Forest Survey of India, Ministry of Environment and Forest, Government of India) Online.www.fsi.nic.in. Accessed on Apr 2018.

11. Precipitation and its Relation to Vegetation (Global Landscapes Forum Bonn. 2017) December 19-20.

12. D. Sheir, D. Murdiyrse, How forest attract rain: an examination of new hypothesis. BioSci. 59(4), 341-347 (2009)

13. Fourth Census of Minor Irrigation Works, (Department of Minor Irrigation, Government of Uttar Pradesh India, 2009, the Reference year 2006-07)

14. Composite Water Management Index Report (Niti Ayog, Government of India, New Delhi, 2018) Online. http://niti.gov. in/content/composite-water-management-index-June-2018

15. Siegel, S.M. Let there Be water, (St. Martin's Press, 178 Fifth Avenue New York, 2015)

16. Frequently Asked Questions on Waste Water (India Water Portal) Online. http://www.indiawaterportal.org/. Accessed in Aug 2020

17. Introduction in Waste Water Generation and Treatment: Domestic.Online.www.cpcbenvis.nic.in. Accessed in Aug 2020

18. Chaurasia, P.R. " Legal and Institutional Framework for Ground Water Management-Status and Issues”, August 20-21, 2009, Lucknow, India, State Water Resource Agency, U.P. and State Water Resources Data Analysis Center U.P. Proceeding, of the State Level Workshop on Ground Water Management in Uttar Pradesh-Challenges, Priorities, and Strategies.

Publisher's Note Springer Nature remains neutral with regard to jurisdictional claims in published maps and institutional affiliations. 